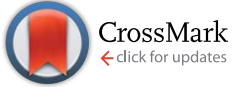

Cite this: J. Mater. Chem. A, 2015, 3, 10949

\section{Nickel oxide interlayer films from nickel formate- ethylenediamine precursor: influence of annealing on thin film properties and photovoltaic device performance $\dagger$}

\author{
K. X. Steirer, ${ }^{\text {acd }}$ R. E. Richards, ${ }^{a}$ A. K. Sigdel,,${ }^{\text {bc }}$ A. Garcia, $\S^{c}$ P. F. Ndione, ${ }^{c}$ \\ S. Hammond, ${ }^{c}$ D. Baker, $q^{d}$ E. L. Ratcliff, ${ }^{e}$ C. Curtis, ${ }^{c}$ T. Furtak, ${ }^{d}$ D. S. Ginley, ${ }^{c}$ \\ D. C. Olson, ${ }^{c}$ N. R. Armstrong ${ }^{a}$ and J. J. Berry*c
}

Received 21st February 2015 Accepted 15th April 2015

DOI: $10.1039 / \mathrm{c} 5 \mathrm{ta} 01379 \mathrm{~h}$

www.rsc.org/MaterialsA
An organometallic ink based on the nickel formate-ethylenediamine $\left(\mathrm{Ni}\left(\mathrm{O}_{2} \mathrm{CH}\right)_{2}(\mathrm{en})_{2}\right)$ complex forms high performance $\mathrm{NiO}_{x}$ thin film hole transport layers (HTL) in organic photovoltaic (OPV) devices. Improved understanding of these HTLs functionality can be gained from temperature-dependent decomposition/ oxidation chemistries during film formation and corresponding chemical structure-function relationships for energetics, charge selectivity, and transport in photovoltaic platforms. Investigations of as-cast films annealed in air (at $150{ }^{\circ} \mathrm{C}-350{ }^{\circ} \mathrm{C}$ ), with and without subsequent $\mathrm{O}_{2}$-plasma treatment, were performed using thermogravimetric analysis, Fourier transform infrared spectroscopy, ultraviolet and X-ray photoelectron spectroscopy, and spectroscopic ellipsometry to elucidate the decomposition and oxidation of the complex to $\mathrm{NiO}_{x}$. Regardless of the anneal temperature, after exposure to $\mathrm{O}_{2}$-plasma, these HTLs exhibit work functions greater than the ionization potential of a prototype donor polymer poly $\left(N-9^{\prime}\right.$-heptadecanyl-2,7carbazole-alt-5,5-(4', $7^{\prime}$-di-2-thienyl-2', $1^{\prime}, 3^{\prime}$-benzothiadiazole) (PCDTBT), thereby meeting a primary requirement of energy level alignment. Thus, bulk-heterojunction (BHJ), OPV solar cells made on this series of $\mathrm{NiO}_{x} \mathrm{HTLs}$ all exhibit similar open circuit voltages $\left(V_{\text {oc }}\right)$. In contrast, the short circuit currents increase significantly from 1.7 to $11.2 \mathrm{~mA} \mathrm{~cm}{ }^{-2}$ upon increasing the anneal temperature from $150{ }^{\circ} \mathrm{C}$ to $250{ }^{\circ} \mathrm{C}$. Concomitantly, increased conductivity and electrical homogeneity of $\mathrm{NiO}_{x}$ thin films are observed at the nanoscale using conductive tip-AFM. Similar $V_{\text {oc }}$ observed for all the $\mathrm{O}_{2}$-plasma treated $\mathrm{NiO}_{x}$ interlayers and variations to nanoscale conductivity suggest that the HTLs all form charge selective contacts and that their carrier extraction efficiency is determined by the amount of precursor conversion to $\mathrm{NiO}_{x}$. The separation of these two properties: selectivity and conductivity, sheds further light on charge selective interlayer functionality.

\section{Introduction}

High efficiency bulk heterojunction (BHJ) organic photovoltaic (OPV) devices often require contacts modified with hole or

\footnotetext{
${ }^{a}$ Department of Chemistry and Biochemistry, University of Arizona, Tucson, Arizona, USA

${ }^{b}$ Department of Physics and Astronomy, University of Denver, Denver, Colorado, USA 'National Renewable Energy Laboratory, Golden, Colorado, USA. E-mail: Kenneth. Steirer@NREL.GOV; Joseph.Berry@NREL.GOV

${ }^{d}$ Applied Physics Department, Colorado School of Mines, Golden, Colorado, USA ${ }^{e}$ Department of Materials Science and Engineering, University of Arizona, Tucson, Arizona, USA

$\dagger$ Electronic supplementary information (ESI) available: XPS of N 1s, UPS and additional FTIR for $\mathrm{NiO}_{x}$ films. See DOI: 10.1039/c5ta01379h

\$ Present address: Intel Corporation, Portland, OR, USA.

$\S$ Present address: Next Energy Technologies Inc. Santa Barbara, CA, USA.

If Present address: Washington Nanofabrication Facility at the University of Washington, Seattle WA, USA.
}

electron charge-transport interlayers in order to increase the charge carrier collection efficiency above that of the unmodified transparent conducting oxide or metal contact., ${ }^{1,2}$ The efficiency of charge collection interlayers relies upon their thin film conductivity, ${ }^{3}$ work function $\left(\Phi_{\mathrm{w}}\right),{ }^{4-7}$ alignments of interlayer valence and conduction band edges with the highest occupied molecular orbital (HOMO) and lowest unoccupied molecular orbital (LUMO) energies across the heterojunction, ${ }^{8-12}$ as well as the degree of heterogeneity for the contact surface. ${ }^{13}$ The combination of these mechanisms provide for selective charge collection in competition with bimolecular and surface recombination under low internal electric fields (i.e. near open-circuit conditions). ${ }^{14-16}$ In particular, the importance of selectivity and contact-extraction efficiency becomes increasingly important in solution-processed photovoltaic platforms as free carrier mobilities of photo-active layers increase. Metal oxides formed with $\mathrm{Mo}, \mathrm{V}, \mathrm{W}, \mathrm{Ni}$ or $\mathrm{NiCo}^{6}$ have been shown to exhibit favorable attributes as hole transport layers (HTLs). Photovoltaic 
applications in organic-,${ }^{17-22}$ colloidal quantum structure- ${ }^{23,24}$ and methyl ammonium lead halide-based platforms ${ }^{25-27}$ utilize HTLs with high transmission at operational wavelengths and work function $\left(\Phi_{\mathrm{w}}\right)$ values equal to or in excess of the donor IP value, although presumably due to different mechanisms for $\mathrm{n}$ and p-type oxides. The grand challenge in contact design remains to effectively create solution-processed deposition methods for high performing thin film devices while still maintaining material and interfacial functionalities outlined above.

$\mathrm{NiO}_{x}$, is one of few p-type metal oxides that has transversed numerous energy relevant technologies such as catalysis, batteries, fuel cells and photovoltaics. Hence, it is of fundamental interest and several organometallic precursor formulations compatible with solution processing have been identified for thin film formation. Examples of these are: nickel acetate tetrahydrate complexed with methanolamine $\left(275^{\circ} \mathrm{C}\right) ;{ }^{28}$ nickel nitrate hexahydrate with monoethanolamine $\left(500{ }^{\circ} \mathrm{C}\right)^{29}$ and nickel formate dihydrate with ethylenediamine $\left(250{ }^{\circ} \mathrm{C}\right) .{ }^{30}$ Lowering the processing temperature required to convert these precursors to the oxide allows use of plastic substrates, which in general cannot tolerate prolonged processing above $150{ }^{\circ} \mathrm{C} .{ }^{31}$ There is considerable literature precedent for the decomposition of nickel formate to form $\mathrm{Ni}$ and $\mathrm{NiO}^{32-38}$ Diamine complexation with nickel formate lowers the thermal requirement for decomposition and thus enables formation of $\mathrm{NiO}_{x}$ at lower temperature. Solutions made with the complexed organometallic precursor in ethylene glycol and water allow fabrication of $\mathrm{NiO}_{x}$ thin films by spin coating the nickel formateethylenediamine-ethylene glycol-water $\left(\mathrm{Ni}\left(\mathrm{O}_{2} \mathrm{CH}\right)_{2}\right.$-en-egwater) ink followed by thermal annealing in air. Formation of $\mathrm{NiO}_{x}$ by this method is unique as it produces conformal, high performance thin films with few processing steps.

A detailed understanding of the interconnected decomposition chemistry with the material and interface functionality can drive metal oxide ink development beyond empirical approaches. For example, exposure to reactive oxygen during annealing may further reduce thermal post-treatments. Zhai et al. demonstrated this relaxation in processing conditions for the acetate precursor, below $150{ }^{\circ} \mathrm{C} .{ }^{39}$ As a direct result of the film growth and processing, $\mathrm{NiO}_{x}$ interlayers strongly affect the OPV device performance. ${ }^{28,30,40}$ After annealing in air and treating with an $\mathrm{O}_{2}$-plasma, $\mathrm{NiO}_{x}$ outperforms a benchmark HTL of poly(ethylene dioxythiophene):poly(styrene sulfonate) (PEDOT:PSS) in prototypical OPV devices using the BHJ poly[ $\mathrm{N}$ $9^{\prime}$-heptadecanyl-2,7-carbazole-alt-5,5-(4',7'-di-2-thienyl-2', $1^{\prime}, 3^{\prime}$ benzothiadiazole] (PCDTBT):[6,6]-phenyl-C71 butyric acid methyl ester $\left(\mathrm{PC}_{70} \mathrm{BM}\right) .{ }^{20}$ When $\mathrm{NiO}_{x}$ interlayers are included in OPV devices, the surface chemistry, band edge energies and mid-gap defect states determine the surface electrical properties and charge selectivity towards holes. Detailed spectroscopic analyses of these solution-deposited $\mathrm{NiO}_{x}$ thin films have shown that these are complex $\mathrm{NiO}_{x}$ surfaces, with a wide range of possible oxide stoichiometries that influence their optoelectronic properties, and their interactions with semiconductors such as those found in organic and hybrid photovoltaic platforms. ${ }^{8,25-27,41}$ Previous UPS and XPS measurements on these films correlated surface hydroxyl species and their dipolar character with an increased band gap energy and improved band edge alignment with BHJ films. ${ }^{8,41}$ More specifically, the $\mathrm{NiO}_{x}$ surface formed from decomposition of these solution precursors is comprised predominantly of a mixture of $\mathrm{NiO}_{x}$, $\mathrm{Ni}(\mathrm{OH})_{2}$ and $\mathrm{NiOOH}$, as revealed by XPS characterization. ${ }^{41}$ The dipolar character of this modified surface leads to a high $\Phi_{\mathrm{w}}$ and favorable energetic matching to the highest occupied molecular orbital $\left(\mathrm{HOMO}_{\mathrm{D}}\right)$ hole-transport energy level of PCDTBT, while the wide band gap, and an apparent lack of mid-gap states, functions to block reverse electron transfer from the lowest unoccupied molecular orbital $\left(\mathrm{LUMO}_{\mathrm{A}}\right)$ of the fullerene electron acceptor. ${ }^{\mathbf{8}, 20,41}$ Furthermore, as these processing conditions for the $\mathrm{NiO}_{x}$ interlayers led to variations in the measured local density of states observed in UPS, this resulted in higher hole selectivity and lower leakage currents in hole only devices. ${ }^{41}$ Through improved charge selectivity and limiting carrier injection from the contact, these $\mathrm{NiO}_{x}$ interlayers lower leakage current and increase shunt resistance in OPV devices..$^{14,42}$ However, systematic investigation of precursor decomposition in relation to device performance has yet to be addressed and hence, is the focus of this paper.

Here, we study the effects of varying the annealing temperature between $150{ }^{\circ} \mathrm{C}$ and $350^{\circ} \mathrm{C}$ for thin films spin coated from the $\mathrm{Ni}\left(\mathrm{O}_{2} \mathrm{CH}\right)_{2}-$ en-eg-water formulation. The effects of incomplete precursor decomposition are important to understanding their influence on the interlayer optoelectronic properties and the ability to collect photocurrent in OPV devices. We observe changes to both the chemical and electronic properties of the resulting $\mathrm{NiO}_{x}$ thin films that correlate with large changes in short-circuit photocurrent $\left(J_{\mathrm{sc}}\right)$ and little to no changes in opencircuit photovoltage $\left(V_{\text {oc }}\right)$ in PCDTBT:PC ${ }_{70} \mathrm{BM}$ OPV devices. Decomposition/oxidation reactions for the films were investigated by thermal gravimetric analysis (TGA), differential scanning calorimetry (DSC), Fourier transform infrared absorption spectroscopy (FTIR) and X-ray photoelectron spectroscopy (XPS). By increasing the anneal temperature for thin films spincoated from the $\mathrm{Ni}\left(\mathrm{O}_{2} \mathrm{CH}\right)_{2}$-en-eg-water ink, from $150{ }^{\circ} \mathrm{C}$ to above $250{ }^{\circ} \mathrm{C}$, and subjecting the films to an $\mathrm{O}_{2}$-plasma, amorphous thin films are formed with: (i) increased conductivity as measured by conductive AFM; (ii) increased surface oxygen content (O/Ni ratio revealed by XPS); (iii) increase of the $\mathrm{NiO}_{x}$ band gap; (iv) high performance in OPV devices, as revealed by analysis of their series resistance and $J_{\mathrm{sc}} . V_{\mathrm{oc}}$ is shown to be affected primarily by the surface oxidation chemistry of $\mathrm{NiOOH}$ even if the precursor decomposition/oxidation is incomplete, while losses observed in $J_{\text {sc }}$ depend primarily upon the nanoscale conductivity threshold reached upon decomposition of the Ni-formate-diamene complex. These studies decouple the underlying oxide formation from the surface effects by $\mathrm{O}_{2}$ plasma treating for photovoltaic device applications.

\section{Experimental}

\section{Ink preparation}

Preparation of the $\mathrm{Ni}\left(\mathrm{O}_{2} \mathrm{CH}\right)_{2}$-en-eg precursor formulation for $\mathrm{NiO}_{x}$ films has been reported earlier. ${ }^{30}$ To summarize, nickel 
formate $(1 \mathrm{~g})$ was combined with ethylene glycol $(10 \mathrm{ml})$ followed by ethylenediamine $(0.87 \mathrm{ml})$. The mixture was heated and shaken multiple times, and then filtered at near ambient temperature through a $0.45 \mu \mathrm{m}$ pore filter. The ink was a deep purple color, consistent with the violet color reported for $\mathrm{Ni}\left(\mathrm{O}_{2} \mathrm{CH}\right)_{2}(\mathrm{en})_{2} \cdot{ }^{43}$ For spin coating, the ink was diluted $1: 1$ by volume with water (nanopure).

\section{Thin films \& devices}

Patterned ITO substrates were first solvent cleaned in acetone and isopropyl alcohol followed by an $\mathrm{O}_{2}$-plasma treatment. $\mathrm{NiO}_{x}$ films were deposited by spin coating the $\mathrm{Ni}\left(\mathrm{O}_{2} \mathrm{CH}\right)_{2}$-en-eg-water ink at $4000 \mathrm{rpm}$ onto the ITO substrates and immediately annealing the films in air at $150-400{ }^{\circ} \mathrm{C}$ for one hour. After annealing, all $\mathrm{NiO}_{x}$ layers were exposed to $\mathrm{O}_{2}$-plasma treatment for 2 minutes at $155 \mathrm{~W}$ and 800 mTorr. The $1: 4$ ratio PCDTBT: $\mathrm{PC}_{70} \mathrm{BM}$ solution was prepared in 1,2-dichlorobenzene under an inert atmosphere at a total concentration of $35 \mathrm{mg} \mathrm{ml}^{-1}$. The solution was stirred at 90 ${ }^{\circ} \mathrm{C}$ for 8 hours before cooling to $60{ }^{\circ} \mathrm{C}$ followed by immediate use, which is a variation on a previously reported procedure. ${ }^{20}$ Spin coated active layers were deposited on top of the $\mathrm{NiO}_{x}$ HTL films at a spin rate of $2000 \mathrm{rpm}$ for 120 seconds. The coated substrates were annealed at $70{ }^{\circ} \mathrm{C}$ on a hot plate for one hour. Top electrodes composed of $\mathrm{Ca} / \mathrm{Al}(20 \mathrm{~nm} / 100 \mathrm{~nm})$ were thermally evaporated using an Angstrom Engineering thermal evaporator with a base pressure below $1 \times 10^{-7}$ Torr to produce $0.11 \mathrm{~cm}^{2}$ devices. Films of $\mathrm{NiO}_{x}$ were prepared on freshly $\mathrm{O}_{2}$-plasma cleaned $\mathrm{Au}$ substrates for AFM and C-AFM studies.

\section{AFM \& C-AFM}

Scanning probe measurements employed an Asylum Research MFP-3D Atomic Force Microscope in conductive mode (c-AFM) using a Pt/Cr coated conductive tip (ElectricMulti75-G by Budget Sensors Inc.) with a radius less than $25 \mathrm{~nm}$. Both height topography and c-AFM were obtained simultaneously. To obtain a good c-AFM signal, $\mathrm{NiO}_{x}$ films were deposited on top of $\mathrm{Au}-$ coated glass substrates rather than ITO, since ITO has nonuniform conductive regions ${ }^{\mathbf{4 4}}$ and thermally-induced electrical degradation at small length scales. ${ }^{13}$ The Au substrate used for calibration had a highly uniform c-AFM profile at very small sample-to-tip bias (VST). All c-AFM measurements on $\mathrm{NiO}_{x}$ films were at ambient conditions with identical scan parameters such as scan speed and drive amplitude, using a VST of $40 \mathrm{mV}$.

\section{Photoelectron spectroscopy}

Experiments were performed on a Kratos Axis Ultra X-ray photoelectron spectrometer equipped with a monochromatic $\mathrm{Al}$ K-alpha X-ray source ( $h v 1486.6 \mathrm{eV}$ ) and a He UV source ( $h v 21.22$ $\mathrm{eV}$ ). Linear calibration of the binding energy scale for the detector was performed following the procedure outlined by $\mathbf{M}$. P. Seah. ${ }^{45} \mathrm{~A}$ bias of $-10.00 \mathrm{~V}$ was applied to the sample during UPS experiments to spectrally separate the lowest kinetic energy electrons and secondary electrons from the local environment. An Ar sputter-etched, atomically-clean gold sample was measured before characterization of the $\mathrm{NiO}_{x}$ samples to establish the Fermi edge of the spectrometer.

\section{TGA \& DSC}

The ink (nickel formate-ethylenediamine-ethylene glycolwater) was placed in a Pt pan at $120{ }^{\circ} \mathrm{C}$ to evaporate the bulk of the water and ethylene glycol solvent with minimal disruption of the nickel formate-ethylenediamine complex. This procedure was repeated twice to obtain an initial mass of $13.87 \mathrm{mg}$ of the $\mathrm{NiO}_{x}$ film precursor (less ethylene glycol). The pan temperature was increased at $10{ }^{\circ} \mathrm{C} \mathrm{min}^{-1}$ under dry synthetic air $(20 \%$ $\mathrm{O}_{2}, 80 \% \mathrm{~N}_{2}$ ) in a TA Instruments SDT Q600 operated in TGA/ DSC mode.

\section{FTIR}

Transmission spectra were measured using a Thermo-Nicolet 6700 FTIR. A liquid $\mathrm{N}_{2}$-cooled mercury-cadmium-telluride (MCT) detector and a $\mathrm{KBr}$ beamsplitter were used. Scans were collected to provide data with a resolution of $2 \mathrm{~cm}^{-1}$. For each measurement 100 scans were averaged for both the sample and the background. Absorbance spectra were calculated from the sample and background using the Beer-Lambert equation.

\section{Ellipsometry}

Thin film optical properties and thicknesses $(9.5 \pm 0.5 \mathrm{~nm})$ were characterized using an M-2000 spectroscopic ellipsometer (J.A. Woolam Co Inc.) at wavelengths of 250-1000 nm and angle of 65-75 degrees. Spectroscopic ellipsometry data were processed with the aid of WVASE software. The $\mathrm{NiO}_{x}$ complex refractive index constants $(N=n-\mathrm{i} k)$ were obtained using a Lorentz parameterized model, which is consistent with the KramersKronig relations. Thicknesses were verified using a Dektak 8 stylus profilometer.

\section{Results and discussion}

\section{Decomposition and oxidation of $\mathrm{Ni}\left(\mathrm{O}_{2} \mathrm{CH}\right)_{2}(\mathrm{en})_{2}$}

Decomposition and oxidation processes for the metal organic precursor depends on the nickel complex formed in solution and spin cast into films. We follow the conversion to $\mathrm{NiO}_{x}$ with TGA and DSC shown in Fig. 1. Previous literature isothermal studies have reported the complete decomposition/oxidation of $\mathrm{Ni}\left(\mathrm{O}_{2} \mathrm{CH}\right)_{2} \cdot 2 \mathrm{H}_{2} \mathrm{O}$ (at $240{ }^{\circ} \mathrm{C}-280{ }^{\circ} \mathrm{C}$ in air) ${ }^{38}$ and $\mathrm{Ni}\left(\mathrm{O}_{2} \mathrm{CH}\right)_{2}$ (at 215-250 ${ }^{\circ} \mathrm{C}$ in oxygen and $242-262{ }^{\circ} \mathrm{C}$ in air). ${ }^{35,36}$ For example, $\mathrm{Ni}\left(\mathrm{O}_{2} \mathrm{CH}\right)_{2} \cdot 2 \mathrm{H}_{2} \mathrm{O}$ was converted to $\mathrm{NiO}$ in less than an hour at $240{ }^{\circ} \mathrm{C}-280{ }^{\circ} \mathrm{C}$ in air. ${ }^{38}$ This is consistent with the expectation that the films annealed in this study at $250{ }^{\circ} \mathrm{C}$ or $300{ }^{\circ} \mathrm{C}$ in air should be comprised of $\mathrm{NiO}_{x}$, which is also supported by the decomposition/oxidation temperature for the $\mathrm{Ni}\left(\mathrm{O}_{2} \mathrm{CH}\right)_{2}(\mathrm{en})_{2}$ complex observed by TGA/DSC in Fig. 1 . Narain reported the synthesis of $\mathrm{Ni}\left(\mathrm{O}_{2} \mathrm{CH}\right)_{2}(\mathrm{en})_{2}$, which should be robust at $120{ }^{\circ} \mathrm{C}$ without any loss of the ethylenediamine ligand. ${ }^{43}$ Therefore, the DSC/TGA measurements (Fig. 1) were performed in a Pt pan on an ink sample after two rounds of evaporation of the bulk of the ethylene glycol and water solvents at $120^{\circ} \mathrm{C}$, leaving a sufficient mass of primarily the $\mathrm{Ni}\left(\mathrm{O}_{2} \mathrm{CH}\right)_{2}(\mathrm{en})_{2}$ complex. On heating in synthetic air $\left(80 \% \mathrm{~N}_{2}, 20 \% \mathrm{O}_{2}\right)$, a small endothermic peak is evident near $125{ }^{\circ} \mathrm{C}$, with a corresponding mass loss of $c a .5 \%$, which is interpreted as a loss of residual solvent (water, ethylene 


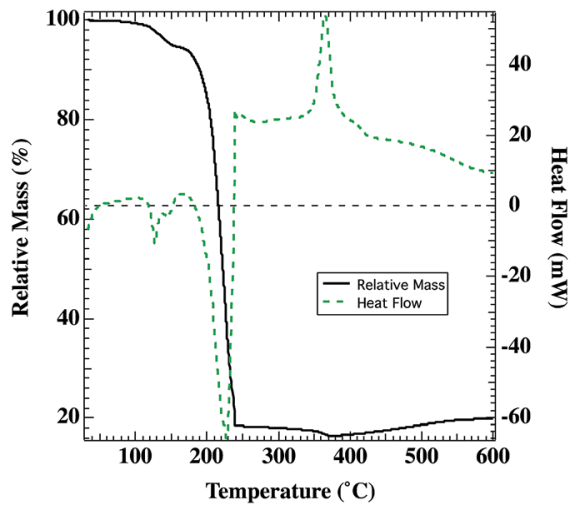

Fig. 1 Thermal gravimetric analysis of the $\mathrm{Ni}\left(\mathrm{O}_{2} \mathrm{CH}\right)_{2}(\mathrm{en})_{2}$ precursor after evaporation of ethylene glycol and water (black). Differential scanning calorimetry data for the same thermal scan (green-dotted).

glycol, excess ethylenediamine). Between $180-240{ }^{\circ} \mathrm{C}$, an additional $77 \%$ of the initial mass $\left(81 \%\right.$ of mass at $\left.150{ }^{\circ} \mathrm{C}\right)$ is lost in an endothermic process, which is comparable to the expected $72 \%$ mass change for conversion of $\mathrm{Ni}\left(\mathrm{O}_{2} \mathrm{CH}\right)_{2}(\mathrm{en})_{2}$ to $\mathrm{NiO}$. Mass loss is due to a combination of evaporation of residual solvent (likely ethylene glycol, boiling point $197^{\circ} \mathrm{C}$ ), loss of the ethylenediamine ligands, which have been shown to leave stepwise, ${ }^{46-48}$ and the decomposition/oxidation of the $\mathrm{Ni}\left(\mathrm{O}_{2} \mathrm{CH}\right)_{2}$ complex (above $225^{\circ} \mathrm{C}$ ) to $\mathrm{NiO}_{x} \cdot{ }^{34,36,38}$ In comparison, studies with $\left[\mathrm{Ni}(\text { saccharinate })_{2}(\mathrm{en})_{2}\right] \mathrm{en}^{47} \quad\left[\mathrm{Ni}(\mathrm{en})_{3}\right]$ oxalate, ${ }^{48}$ $\mathrm{Ni}\left(\right.$ succinate)(en), ${ }^{49}$ and $\mathrm{Ni}(\mathrm{en})_{3} \mathrm{SO}_{4}$ (ref. 50) reported temperatures for the final stage decomposition/oxidation to NiO of 300 ${ }^{\circ} \mathrm{C}, 325{ }^{\circ} \mathrm{C}, 410{ }^{\circ} \mathrm{C}$, and $466{ }^{\circ} \mathrm{C}$ respectively. On further heating, there is some additional mass lost (ca. $2 \%$ of the initial mass) until $375{ }^{\circ} \mathrm{C}$, when an exothermic transition is seen and correlates with a gradual mass increase. Hence, the $\mathrm{Ni}\left(\mathrm{O}_{2} \mathrm{CH}\right)_{2}(\mathrm{en})_{2}$ complex is to date, preferred for lower temperature formation of solution-deposited $\mathrm{NiO}_{x}$ but photovoltaic applications require subsequent surface treatments to increase the work-function. ${ }^{7,30}$

\section{Chemical composition characterization}

Surface elemental composition determined from XPS measurements confirmed predominant $\mathrm{NiO}_{x}$ composition as well as the presence of $\mathrm{C}$ and $\mathrm{N}$ due to the $\mathrm{O}_{2}$-plasma treatment and ambient exposure prior to measurement (see Table 1). $\mathrm{O}_{2}$-plasma is known to remove adventitious organic compounds. However, the $\mathrm{N}$ content in the films likely originates from the ethylenediamine, which decreases as the anneal temperature increases from $150^{\circ} \mathrm{C}$ to $250^{\circ} \mathrm{C}$. Yet, after correcting for the $\mathrm{C} 1 \mathrm{~s}$ binding energy (BE) the $\mathrm{BE}$ values for $\mathrm{N}$ 1 s peak centroids are located at $406.6 \mathrm{eV}$ (see S1 $\dagger$ ) and are too high to be explained by the presence of unreacted amine groups. A more likely assignment consistent with the $\mathrm{O}_{2}$ plasma treatment is one or more forms of near surface $\mathrm{N}-\mathrm{O}$ species such as $-\mathrm{NO}_{3}$, which can be identified using vibrational spectroscopy.

Exposure of the $\mathrm{NiO}_{x}$ thin films to $\mathrm{O}_{2}$-plasma predominantly affects the exposed surface creating similar structures for all the films while providing less effect on the subsurface
Table 1 Surface atomic composition of spin-coated $\left(\mathrm{NiO}_{x}\right)$ films calculated from XPS peaks normalized to photoemission sensitivity factors: Ni $2 p, C 1 s, O 1 s$ and $N$ 1s. Work function $\left(\Phi_{w}\right)$ values were calculated from UPS data. All films were $\mathrm{O}_{2}$-plasma treated. Satellites for $\mathrm{Ni} 2 \mathrm{p}$ photoelectrons were omitted from area calculations. Error is $\pm 10 \%$

\begin{tabular}{lllllll}
\hline $\begin{array}{l}\text { Anneal } T \\
\left({ }^{\circ} \mathrm{C}\right)\end{array}$ & $\mathrm{Ni}(\%)$ & $\mathrm{O}(\%)$ & $\mathrm{C}(\%)$ & $\mathrm{N}(\%)$ & $\mathrm{O} / \mathrm{Ni}$ & $\Phi_{\mathrm{w}}(\mathrm{eV})$ \\
\hline 150 & 33 & 55 & 8 & 4 & 1.7 & 5.4 \\
200 & 29 & 56 & 12 & 3 & 2.0 & 5.4 \\
250 & 27 & 60 & 11 & 2 & 2.2 & 5.5 \\
300 & 26 & 62 & 10 & 2 & 2.4 & 5.5
\end{tabular}

material. We analyzed FTIR spectra taken for $\mathrm{NiO}_{x}$ thin films to understand the $\mathrm{O}_{2}$-plasma effects for the whole system. FTIR spectra are shown in Fig. 2 for films spin-coated from the $\mathrm{Ni}\left(\mathrm{O}_{2} \mathrm{CH}\right)_{2}$-en-eg-water ink, comparing the as-deposited film ('no anneal') to films annealed for one hour in air at 150 ${ }^{\circ} \mathrm{C}, 200{ }^{\circ} \mathrm{C}, 250{ }^{\circ} \mathrm{C}$ or $300{ }^{\circ} \mathrm{C}$. Band assignments for chemical constituents of the film precursor are listed in Table 2 . The major band assignments reported in the literature for the fundamental vibrations of the formate group in nickel formate (dihydrate) are the $\nu_{1} \nu(\mathrm{CH})$ mode at $c a .2900 \mathrm{~cm}^{-1}$, the intense $\nu_{4} \nu_{\text {as }}(\mathrm{COO})$ mode at $c a .1570 \mathrm{~cm}^{-1}$, and asymmetric deformation $\left(\nu_{5} \delta(\mathrm{C}-\mathrm{H})\right)$ and symmetric stretch $\left(\nu_{2}\right.$ $\nu_{\mathrm{s}}(\mathrm{COO})$ ) modes between $1400-1350 \mathrm{~cm}^{-1} \cdot{ }^{34,51-53}$ For liquid ethylene glycol, the major band assignments reported in the literature are the strong $\nu(\mathrm{OH})$ stretching mode at 3400-3150
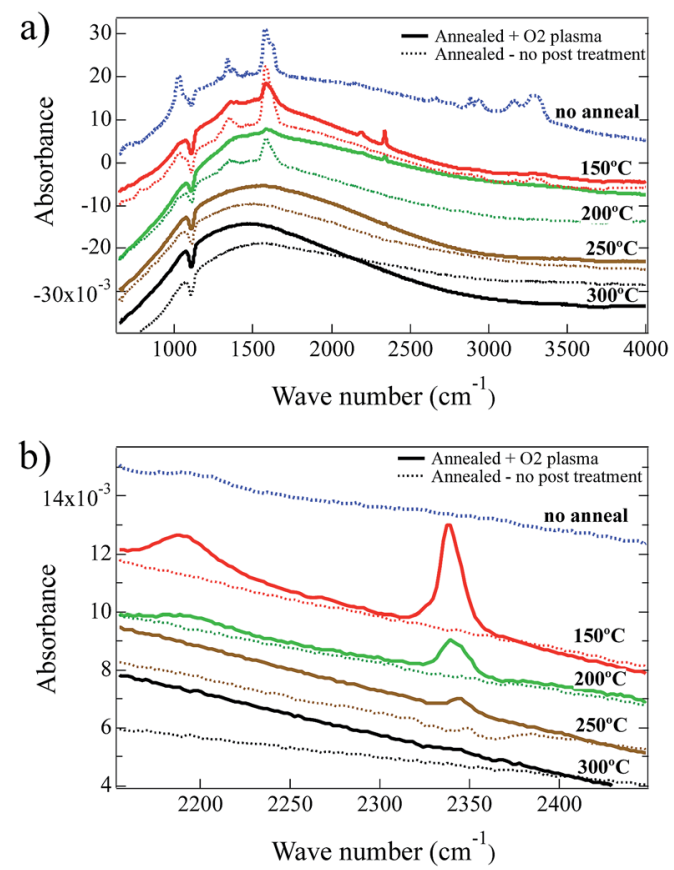

Fig. 2 FTIR results for spin-coated $\left(\mathrm{NiO}_{x}\right)$ thin films on $\mathrm{Si}$ wafers, comparing without anneal and annealed conditions $\left(150{ }^{\circ} \mathrm{C}, 200^{\circ} \mathrm{C}\right.$, $250{ }^{\circ} \mathrm{C}$ and $300{ }^{\circ} \mathrm{C}$ ). Films that received $\mathrm{O}_{2}$-plasma treatment are indicated. Spectra are offset in order to clearly show the spectral changes. 
Table 2 Peak assignments for FTIR spectra shown in Fig. 2

\begin{tabular}{|c|c|c|c|}
\hline Wavenumber $\left(\mathrm{cm}^{-1}\right)$ & Assignment & Source of vibration & Reference \\
\hline 1018 & $\nu(\mathrm{CN})$ & Ethylenediamine (ligand) & $1-3$ \\
\hline 1027 & $\nu(\mathrm{CO})$ & Ethylene glycol & 4 and 5 \\
\hline 1371 & $\nu_{5} \delta(\mathrm{CH}) \nu_{2} \nu_{\mathrm{s}}(\mathrm{COO})$ & Formate & $6-9$ \\
\hline 1458 & $\delta\left(\mathrm{CH}_{2}\right)$ & Ethylene glycol & 4 and 5 \\
\hline 1587 & $\nu_{4} \nu_{\mathrm{as}}(\mathrm{COO})$ & Formate & $6-9$ \\
\hline 2340 & $\nu_{3} \nu_{\mathrm{as}}\left(\mathrm{CO}_{2}\right)$ & $\mathrm{CO}_{2}$ & $14-16$ \\
\hline \multirow[t]{2}{*}{2884} & $\nu_{1} \nu(\mathrm{C}-\mathrm{H})$ & Formate & $6-9$ \\
\hline & $\nu_{\mathrm{s}}(\mathrm{CH})$ & Ethylene glycol & 4 and 5 \\
\hline \multirow[t]{2}{*}{2936} & $\nu_{\text {as }}(\mathrm{CH})$ & Ethylene glycol & 4 and 5 \\
\hline & $\nu\left(\mathrm{CH}_{2}\right)$ & Ethylenediamine & 1 and 2 \\
\hline $3300-3160$ & $\nu(\mathrm{OH})$ & Ethylene glycol & 4 and 5 \\
\hline
\end{tabular}

$\mathrm{cm}^{-1}$, the strong asymmetric $\left(\nu_{\text {as }}(\mathrm{CH})\right)$ and symmetric $\left(\nu_{\mathrm{s}}(\mathrm{CH})\right)$ stretch modes at $2935 \mathrm{~cm}^{-1}$ and $2875 \mathrm{~cm}^{-1}$ respectively, the strong $\delta\left(\mathrm{CH}_{2}\right)$ mode at $c a .1450 \mathrm{~cm}^{-1}$, and the very strong $\nu(\mathrm{CO})$ and $\nu(\mathrm{CC})$ modes at $1100-1050 \mathrm{~cm}^{-1} .^{54,55}$ IR spectra have not been reported for the complex $\mathrm{Ni}\left(\mathrm{O}_{2} \mathrm{CH}\right)_{2}(\mathrm{en})_{2}$. However, literature reports indicate the major band assignments for ethylenediamine ligands in $\mathrm{Ni}$ (acetylacetonates) $)_{2} \mathrm{en}^{56}$ and $\left[\mathrm{Ni}\right.$ (succinate)(en)] $2 \mathrm{H}_{2} \mathrm{O}^{49}$ complexes to be the asymmetric $\left(\nu_{\text {as }}(\mathrm{NH})\right)$ and symmetric $\left(\nu_{\mathrm{s}}(\mathrm{NH})\right)$ modes at $3350-3150 \mathrm{~cm}^{-1}$, the strong $\delta\left(\mathrm{NH}_{2}\right)$ mode at $1613 \mathrm{~cm}^{-1}$, the $\omega\left(\mathrm{NH}_{2}\right)$ mode at $1318 \mathrm{~cm}^{-1}$, and the strong $\nu(\mathrm{CN})$ mode at $1025 \mathrm{~cm}^{-1}$. These ethylenediamine ligand band assignments for $\mathrm{Ni}$ complexes are consistent with values reported for other transition metal organometallic complexes ${ }^{56-58}$ and also liquid ethylenediamine..$^{59}$

The bands at $c a .1020-1030 \mathrm{~cm}^{-1}(\nu(\mathrm{CN})$ and $\nu(\mathrm{CO}))$ and $c a$. $3200-3350 \mathrm{~cm}^{-1}(\nu(\mathrm{OH}))$ indicate ethylene glycol and/or ethylenediamine ${ }^{\mathbf{5 4 , 5 5 , 5 7 , 5 9 , 6 0}}$ and are discernible only in the no-anneal film and the film annealed at $150{ }^{\circ} \mathrm{C}$ as shown in Fig. 2a. The FTIR spectra indicate that ethylene glycol and ethylenediamine are virtually eliminated by a one hour anneal in air at $200{ }^{\circ} \mathrm{C}$. Bands at $1627 \mathrm{~cm}^{-1}\left(\delta\left(\mathrm{NH}_{2}\right)\right)$, and $1338 \mathrm{~cm}^{-1}\left(\nu_{5} \delta(\mathrm{C}-\mathrm{H})\right)$ and $\left(\nu_{2}\right.$ $\left.\nu_{\mathrm{s}}(\mathrm{COO})\right)$ and $1587 \mathrm{~cm}^{-1}\left(\nu_{4} \nu_{\text {as }}(\mathrm{COO})\right)$, also seen in Fig. 2a, indicate ethylenediamine and formate respectively. ${ }^{34,51-53,57,59,60}$ The formate bands are present in the FTIR spectra for the as spun film and the films annealed at $150{ }^{\circ} \mathrm{C}$ or $200{ }^{\circ} \mathrm{C}$ without an $\mathrm{O}_{2}$-plasma treatment. A one hour anneal in air at $250{ }^{\circ} \mathrm{C}$ and $300{ }^{\circ} \mathrm{C}$ eliminates the formate from the films resulting in a near featureless spectra consistent with $\mathrm{NiO}_{x}$ except for broad bands at ca. $3570 \mathrm{~cm}^{-1}$ that are surface hydroxyls. ${ }^{61-63}$ This result is consistent with the TGA/DSC data described above.

A comparison of the impact of the $\mathrm{O}_{2}$-plasma treatment, typically used for NiO HTLs, is also included in Fig. 2a and b for films annealed for one hour in air at $150{ }^{\circ} \mathrm{C}, 200{ }^{\circ} \mathrm{C}, 250{ }^{\circ} \mathrm{C}$ or $300{ }^{\circ} \mathrm{C}$. The intensities of all the ethylenediamine, ethylene glycol, and formate bands were lowered significantly after treatment with $\mathrm{O}_{2}$-plasma, consistent with an $\mathrm{O}_{2}$-plasma being highly efficient at removing organic compounds from materials and surfaces. After $\mathrm{O}_{2}$-plasma treatment, two new bands emerge in the FTIR spectra located at $2190 \mathrm{~cm}^{-1}$ and $2340 \mathrm{~cm}^{-1}$. The $2190 \mathrm{~cm}^{-1}$ band is present after $\mathrm{O}_{2}$-plasma treatment in the film annealed at $150{ }^{\circ} \mathrm{C}$ (i.e., before the ethylenediamine is eliminated), and is very weak in the film annealed at $200{ }^{\circ} \mathrm{C}$. The 2340 $\mathrm{cm}^{-1}$ band is present in the films annealed at $150{ }^{\circ} \mathrm{C}, 200{ }^{\circ} \mathrm{C}$ and $250{ }^{\circ} \mathrm{C}$ after $\mathrm{O}_{2}$-plasma treatment, although the intensity decreases significantly with increasing temperature consistent with greater conversion decomposition/oxidation of the precursor to $\mathrm{NiO}_{x}$. Given the oxidizing environment in the $\mathrm{O}_{2}$ plasma and the presence of $\mathrm{C}$ and $\mathrm{N}$ in the partially decomposed/oxidized films annealed at $150{ }^{\circ} \mathrm{C}$ and $200{ }^{\circ} \mathrm{C}$, the 2190 $\mathrm{cm}^{-1}$ band is tentatively assigned to the $\nu(\mathrm{C}-\mathrm{N})$ modes for oxygen-bonded cyanate (OCN) groups or nitrogen-bonded isocyanate (NCO) groups to $\mathrm{Ni}^{2+}$ : rather than the stretch modes of $\mathrm{C}=\mathrm{N}$ in a carbon nitride film. ${ }^{64}$ For example, $\nu(\mathrm{CN})$ modes have been reported at $c a .2200 \mathrm{~cm}^{-1}$ for the nickel isocyanate complex $\left[\mathrm{Et}_{4} \mathrm{~N}\right]_{2}\left[\mathrm{Ni}(\mathrm{NCO})_{4}\right],{ }^{65} \mathrm{CNO}^{-}$intercalated in $\alpha-\mathrm{Ni}(\mathrm{OH})_{2}$ (ref. 66) and a theoretical study of the adsorption of cyanate and isocyanate on a $\mathrm{Ni}(100)$ surface; ${ }^{67}$ and at $2262 \mathrm{~cm}^{-1}$ and 2200 $\mathrm{cm}^{-1}$ for $\mathrm{Ni}(\mathrm{NCO})_{2} \cdot \mathrm{H}_{2} \mathrm{O},{ }^{68}$ In contrast, a theoretical study of the adsorption of cyanide on a $\mathrm{Ni}(100)$ surface reported the $\nu(\mathrm{CN})$ mode at only $c a .2000 \mathrm{~cm}^{-1},{ }^{69}$ and experimentally the $\nu(\mathrm{CN})$ mode for $\mathrm{Ni}(\mathrm{CN})_{2} \cdot 2 \mathrm{H}_{2} \mathrm{O}$ was reported at $2172 \mathrm{~cm}^{-1} .^{70}$ The 2340 $\mathrm{cm}^{-1}$ band is tentatively assigned to the $\nu_{3} \nu_{\text {as }}\left(\mathrm{CO}_{2}\right)$ mode of $\mathrm{CO}_{2}$ trapped in the films annealed at $150{ }^{\circ} \mathrm{C}-200{ }^{\circ} \mathrm{C}$ after $\mathrm{O}_{2}$-plasma treatment of the partially decomposed/oxidized $\mathrm{Ni}\left(\mathrm{O}_{2} \mathrm{CH}\right)_{2}(\mathrm{en})_{2}$ complex. Similar IR bands have been reported for free $\mathrm{CO}_{2}$ trapped during the thermal decomposition in air of hexahydrated nickel iron citrate to form ultrafine $\mathrm{NiFe}_{2} \mathrm{O}_{4}$ particles $\left(2320 \mathrm{~cm}^{-1}\right),{ }^{71}$ propanol $/ \mathrm{TaCl}_{5}$ gel to form $\mathrm{Ta}_{2} \mathrm{O}_{5}$ thin films (at $2345 \mathrm{~cm}^{-1}$ and $2333 \mathrm{~cm}^{-1}$ ), ${ }^{72}$ and zinc acetate dihydrate/sodium hydrogen carbonate mixtures in argon to form $\mathrm{ZnO}$ nanoparticles (at ca. $2340 \mathrm{~cm}^{-1}$ ). ${ }^{73}$ Both of these modes appear to be eliminated after $\mathrm{O}_{2}$-plasma treatment for the film annealed at $300{ }^{\circ} \mathrm{C}$ since decomposition/oxidation of the precursor to $\mathrm{NiO}_{x}$ is complete. However, as described above a small percentage of $\mathrm{N}$ is still observed in the XPS spectra with high BE values for 
$\mathrm{O}_{2}$-plasma treated films, most likely due to near surface $\mathrm{N}-\mathrm{O}$ species such as $-\mathrm{NO}_{3}$. For nickel nitrate the strong $-\mathrm{NO}_{3}$ ion stretching band would appear at ca. $1300-1400 \mathrm{~cm}^{-1} \cdot{ }^{74-76}$ This is also the region where medium strength formate and ethylenediamine bands are anticipated. Confirmation of nitrate cannot be provided by the FTIR spectra after $150{ }^{\circ} \mathrm{C}$ anneal and $\mathrm{O}_{2}$-plasma treatment. However, the peak position of the ethylenediamine $\omega\left(\mathrm{NH}_{2}\right)$ mode shifts from $1338 \mathrm{~cm}^{-1}$ to $1358 \mathrm{~cm}^{-1}$ for the as-deposited, and $150{ }^{\circ} \mathrm{C}$ anneal plus $\mathrm{O}_{2}$-plasma respectively, and may indicate possible spectral contribution from $-\mathrm{NO}_{3}$ ions (see $\mathrm{S} 2 \dagger$ ). After the $200{ }^{\circ} \mathrm{C}$ anneal and $\mathrm{O}_{2}$-plasma treatment, the $1300-1400 \mathrm{~cm}^{-1}$ region is nearly featureless.

FTIR analysis suggests the trapping of $\mathrm{CO}_{2}$ and the formation of N-based anions in the films annealed at the lower temperatures and after an $\mathrm{O}_{2}$-plasma treatment. The confinement of $\mathrm{CO}_{2}$ in solid-state $\mathrm{NiO}_{x}$ films implies that a dense surface barrier forms during the $\mathrm{O}_{2}$-plasma treatment. The cyanate species assigned in the FTIR spectra were not identified in the more surface-sensitive XPS measurements. Moreover, nitrates observed by XPS could not be unambiguously identified with FTIR. These complementary surface and through-film measurements lead to the tentative hypothesis that the low concentration of nitrates are most likely surface confined.

\section{Characterization using spectroscopic ellipsometry}

In order to study the effect of annealing on the optical properties we employed angular dependent UV-vis reflection using spectroscopic ellipsometry. Fig. 3 displays the square of absorbance versus incident photon energy. Absorbance was calculated using the extinction coefficient from Lorentz oscillator model fits to the ellipsometric data. The onset of absorption was extrapolated after a linear fit to the square of the absorption coefficient between 4.1 and $4.4 \mathrm{eV} .^{77}$ For the lowest temperature anneal at $150{ }^{\circ} \mathrm{C}$ the $\mathrm{NiO}_{x}$ absorbance is low and barely resembles the absorption edge of a semiconductor, which is

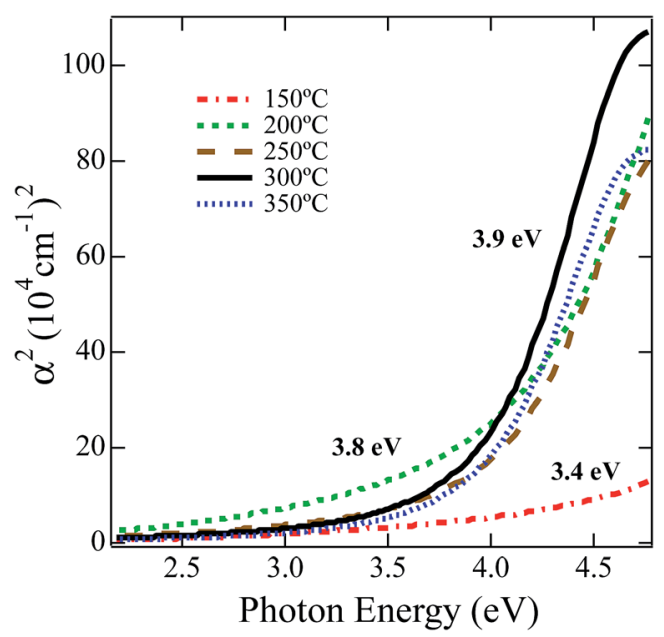

Fig. 3 Square of absorption coefficient plot calculated with $n$ and $k$ measured from spectroscopic ellipsometry versus photon energy. Linear fits were obtained between 4.1 and $4.4 \mathrm{eV}$ for $\left(\mathrm{NiO}_{x}\right)$ films at each anneal temperature. consistent with the minimal decomposition/oxidation of the $\mathrm{Ni}\left(\mathrm{O}_{2} \mathrm{CH}\right)_{2}(\mathrm{en})_{2}$ complex at this temperature. Nevertheless, fitting the onset region results in an estimate for the optical gap of $3.4 \mathrm{eV}$. For the film annealed at $200{ }^{\circ} \mathrm{C}$, the absorbance increases as the precursor has partially decomposed/oxidized resulting in a $3.8 \mathrm{eV}$ estimate of the optical band gap. For films annealed at $250{ }^{\circ} \mathrm{C}$ and $300{ }^{\circ} \mathrm{C}$, because the decomposition of the $\mathrm{Ni}\left(\mathrm{O}_{2} \mathrm{CH}\right)_{2}(\mathrm{en})_{2}$ complex to $\mathrm{NiO}_{x}$ is well advanced the absorption edge is more clearly defined and results in an optical gap estimate of $3.9 \mathrm{eV}$, which is in good agreement with the accepted band gap of $4.0 \mathrm{eV}$ for $\mathrm{NiO} .^{78,79}$

\section{OPV device performance}

To investigate the impact of the $\mathrm{NiO}_{x}$ film composition as a function of annealing temperature, on OPV performance we utilized these films as HTLs, annealed at different temperatures on ITO and integrated them into ITO/ $\mathrm{NiO}_{x} / \mathrm{PCDTBT}_{\mathrm{PC}} \mathrm{C}_{70} \mathrm{BM} /$ $\mathrm{Ca} / \mathrm{Al}$ OPV devices. Current-voltage $(J V)$ measurements were performed under one-sun illumination. The data from these devices are shown in Fig. 4a with calculated performance metrics in Tables 3 and 4.

Power conversion efficiencies (PCE) are shown normalized in Fig. $4 \mathrm{~b}$ and increased from $0.5 \%$ to $5.7 \%$ with increasing anneal temperature between $150{ }^{\circ} \mathrm{C}$ and $250{ }^{\circ} \mathrm{C}$. These PCE values trend directly with short-circuit current density and as a function of thermal annealing temperature. Likewise, the PCE and $J_{\text {sc }}$ inversely trend with $R_{\mathrm{S}}$ as a function of annealing temperature. For the lowest annealing temperatures $\left(150{ }^{\circ} \mathrm{C}\right.$ and $\left.200{ }^{\circ} \mathrm{C}\right)$ the devices suffer from large resistive losses, poor current extraction and low fill factors. At $250{ }^{\circ} \mathrm{C}$ and above the $R_{\mathrm{s}}$ drops substantially and the device performance improves with gains in $J_{\mathrm{sc}}$ and FF. This drop in series resistance within the device is commensurate with the decomposition/oxidation of the $\mathrm{NiO}_{x}$ layer.

It is important to note that the open-circuit voltages do not appear to trend with annealing temperature. Ultraviolet photoelectron spectroscopy (UPS) measurements (see S3†) for these solution-deposited $\mathrm{NiO}_{x}$ films after annealing between $150{ }^{\circ} \mathrm{C}$ and $300{ }^{\circ} \mathrm{C}$ all produce films with very similar work function values that range from 5.4 to $5.5 \mathrm{eV}$ and IP values of 5.7-5.8 $\pm 0.1 \mathrm{eV}$, in agreement with earlier reports. ${ }^{15}$ This is consistent with the relatively uniform $V_{\text {oc }}$ found across the devices when one considers work-function and the interface electronic structure of the contact determining factors of $V_{\mathrm{oc}}$. For the devices annealed at $250{ }^{\circ} \mathrm{C}$ and above there is very little statistically significant difference in the device data. As shown in Table 3, there is a modest increase just above the statistical noise from $250{ }^{\circ} \mathrm{C}$ to $300{ }^{\circ} \mathrm{C}$. It is clear that the compositional changes from annealing the $\mathrm{NiO}_{x}$ HTL to $250{ }^{\circ} \mathrm{C}$ significantly alter the electronic properties and result in enhanced holecollection from the $\mathrm{BHJ}$.

\section{Conductive tip-AFM}

To examine the charge transport across the $\mathrm{NiO}_{x}$ films processed at different temperatures and to better understand holecollecting efficiency, samples were prepared (in an identical way 
a)
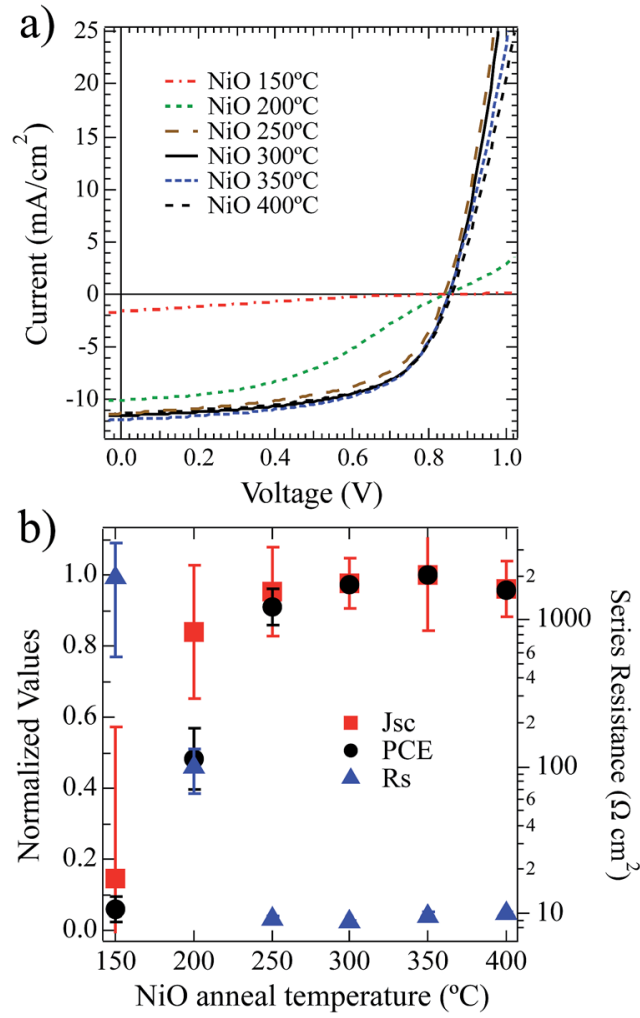

Fig. 4 (a) Current-voltage response of PCDTBT:PC $\mathrm{C}_{70} \mathrm{BM}$ solar cells with increasing anneal temperatures for the $\left(\mathrm{NiO}_{x}\right)$ films spin-coated from the $\mathrm{Ni}\left(\mathrm{O}_{2} \mathrm{CH}\right)_{2}$-en-eg-water solution. (b) Short circuit current $\left(J_{\mathrm{sc}}\right.$ - squares) and power conversion efficiency (PCE - circles) normalized and plotted for the current-voltage curves in (a). $R_{\mathrm{s}}$ taken as the inverse slope at $+1.5 \mathrm{~V}$ is plotted on the right axis. Error bars represent one standard deviation.

to the films used in devices) on Au as opposed to ITO substrates. Gold was used to eliminate underlying effects of electrical heterogeneity of the ITO, compared to the uniform and stable background provided on the gold surface. The nanoscale topography and electrical transport of these films were measured with conductive tip-AFM using a Pt/Ir tip held at the same tip bias for all films. For these experiments the tip forms the top contact on the $\mathrm{Au}-\mathrm{NiO}_{x}$-Pt/Ir tip junction. Fig. 5 shows AFM and c-AFM data for five different anneal temperatures between $150{ }^{\circ} \mathrm{C}$ and $350{ }^{\circ} \mathrm{C}$. The white pixels in the bottom row of Fig. 5 indicate a good electrical transport or an Ohmic junction, while dark pixels indicate poor electrical conductivity
Table 4 Normalized device metrics from Table 3

\begin{tabular}{llllll}
\hline Anneal temp & $V_{\text {oc }}$ norm & $J_{\text {sc }}$ norm & FF norm & PCE norm & $R_{\mathrm{s}}$ norm \\
\hline 150 & 0.98 & 0.14 & 0.38 & 0.06 & 1.0000 \\
200 & 0.97 & 0.84 & 0.59 & 0.48 & 0.0504 \\
250 & 0.99 & 0.96 & 0.96 & 0.91 & 0.0047 \\
300 & 0.99 & 0.98 & 1.00 & 0.97 & 0.0045 \\
350 & 0.99 & 1.00 & 0.99 & 1.00 & 0.0049 \\
400 & 1.00 & 0.96 & 1.00 & 0.96 & 0.0051
\end{tabular}

or diode like behavior. Since all the $\mathrm{NiO}_{x}$ films have similar work functions as seen in Table 1 , we can assume minimal changes in tip-surface injection/extraction barriers. Hence, we conclude that the measured c-AFM data is indicative of changes in the conductivity of the $\mathrm{NiO}_{x}$. Conformal, thin-film coatings were observed for each annealing condition on the $\mathrm{Au}$ substrates. Moreover, XRD analysis of a series of $\mathrm{NiO}_{x}$ thin-films heated from $150{ }^{\circ} \mathrm{C}$ to $350{ }^{\circ} \mathrm{C}$ showed no sign of diffraction peaks. The $150{ }^{\circ} \mathrm{C}$ anneal resulted in an undulating surface topology (1.46 nm RMS) and a highly insulating film with no current transfer between tip and the Au ground. In contrast, the film annealed at $200{ }^{\circ} \mathrm{C}$ has a much flatter surface morphology (0.46 nm RMS) and a small but measurable current, which indicates improved charge transfer with $<10 \%$ area being electrically active. As the annealing temperature is increased from $200{ }^{\circ} \mathrm{C}$ to $350{ }^{\circ} \mathrm{C}$, increases in the $\mathrm{NiO}_{x}$ film roughness and electrical property are observed. After the $250{ }^{\circ} \mathrm{C}$ anneal, the film roughness is $0.65 \mathrm{~nm}$ RMS and conductive regions occupy most of the surface. The $300{ }^{\circ} \mathrm{C}$ anneal results in a $\mathrm{NiO}_{x}$ film with larger protrusions (1.35 $\mathrm{nm}$ RMS) and a sharp increase in the measured current that saturated the $20 \mathrm{nA}$ c-AFM detection limit. The $\mathrm{NiO}_{x}$ films resulting from a $350{ }^{\circ} \mathrm{C}$ anneal exhibits slightly lower conductivity compared to the $300{ }^{\circ} \mathrm{C}$ film, and a further increase in particle/grain size. The improved throughfilm conductivity, as assessed by the area of the saturated pixels, correlate well with lowering of the series resistance and improved current collection for the OPV devices. This suggests that high series resistance for the lower anneal temperatures is a result of the poor conductivity of the HTL, which is a direct result of incomplete precursor decomposition/oxidation.

The large volume fraction of incompletely decomposed precursor results in resistive properties at the nanoscale and macroscale. However, separating improvements to carrier concentration and mobility remains elusive. One would expect

Table 3 Device performance metrics for current-voltage responses reported in Fig. $4 . R_{\mathrm{s}}$ corresponds to the inverse slope at $1.5 \mathrm{~V}$

\begin{tabular}{|c|c|c|c|c|c|c|c|c|c|c|}
\hline $\begin{array}{l}\text { Anneal temp } \\
\left({ }^{\circ} \mathrm{C}\right)\end{array}$ & $\begin{array}{l}V_{\mathrm{oc}} \\
(\mathrm{mV})\end{array}$ & \pm & $\begin{array}{l}J_{\mathrm{sc}} \\
\left(\mathrm{mA} \mathrm{cm}^{-2}\right)\end{array}$ & \pm & $\mathrm{FF}$ & \pm & $\begin{array}{l}\text { PCE } \\
(\%)\end{array}$ & \pm & $\begin{array}{l}R_{\mathrm{s}}-\text { dark } \\
\left(\Omega \mathrm{cm}^{2}\right)\end{array}$ & \pm \\
\hline 150 & 842 & 6 & 1.7 & 0.7 & 0.23 & 0.04 & 0.3 & 0.2 & 1955.1 & 1397.9 \\
\hline 200 & 834 & 11 & 9.8 & 0.3 & 0.35 & 0.05 & 2.8 & 0.5 & 98.6 & 33.7 \\
\hline 250 & 850 & 14 & 11.2 & 0.2 & 0.57 & 0.04 & 5.3 & 0.3 & 9.3 & 0.4 \\
\hline 300 & 852 & 10 & 11.5 & 0.1 & 0.59 & 0.01 & 5.6 & 0.1 & 8.7 & 0.2 \\
\hline 350 & 852 & 7 & 11.7 & 0.3 & 0.58 & 0.00 & 5.7 & 0.1 & 9.7 & 0.6 \\
\hline 400 & 860 & 8 & 11.2 & 0.1 & 0.59 & 0.00 & 5.5 & 0.1 & 10.1 & 0.3 \\
\hline
\end{tabular}



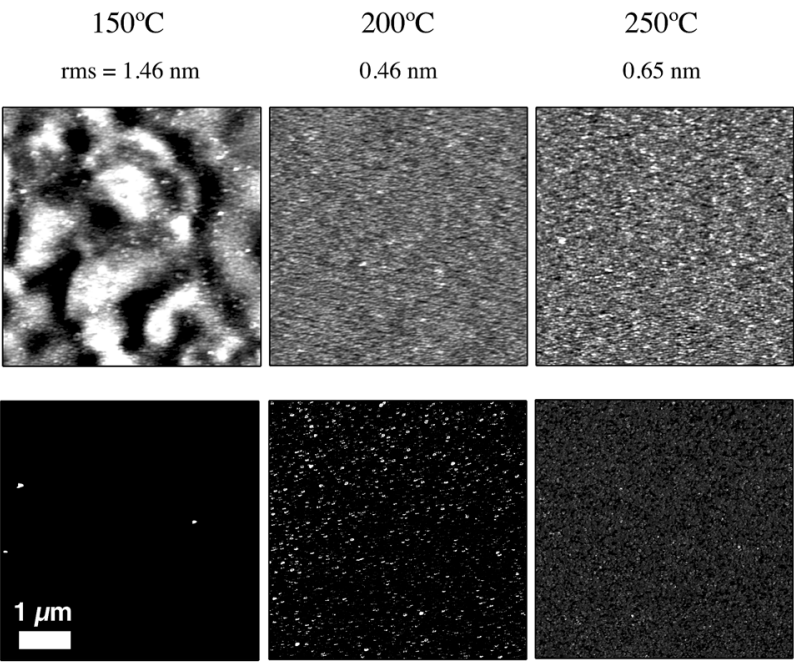

Fig. $5 \mathrm{AFM}$ (top row) and CAFM (bottom row) of $\mathrm{NiO}_{x}$ films deposited on Au. From left-to-right, anneals at $150{ }^{\circ} \mathrm{C}, 200^{\circ} \mathrm{C}, 250{ }^{\circ} \mathrm{C}, 300{ }^{\circ} \mathrm{C}$ and $350{ }^{\circ} \mathrm{C}$ for the spin-coated films. RMS roughness is stated below the corresponding anneal temperature.

that the improved conductivity with annealing temperature occurs due to increases of both mobility and carrier concentrations as the precursor decomposes and formation of $\mathrm{NiO}$ proceeds. Note that the formation of new species (cyanate, isocyanate, or nitrate) after exposing the low temperature $\left(150{ }^{\circ} \mathrm{C}-200{ }^{\circ} \mathrm{C}\right)$ annealed films to $\mathrm{O}_{2}$-plasma, may also contribute to the poor semiconductor properties of these films. However, solution-deposited $\mathrm{NiO}_{x}$ HTLs annealed at $250^{\circ} \mathrm{C}-400$ ${ }^{\circ} \mathrm{C}$, and hence above the decomposition/oxidation temperature of the $\mathrm{Ni}\left(\mathrm{O}_{2} \mathrm{CH}\right)_{2}(\mathrm{en})_{2}$ complex, exhibit compositional changes that improve the nanoscale conductivity. These $\mathrm{NiO}_{x}$ thin films can then effectively collect photogenerated holes from the $\mathrm{BHJ}$ with minimal resistive loss. The sub-stoichiometric nature of the $\mathrm{NiO}_{x}$ produced at low annealing temperatures suggests that in addition to establishing a high work-function, the $\mathrm{O}_{2}$-plasma treatment required for optimal device performance oxidizes the $\mathrm{NiO}_{x}$ but to a large extent is limited to the surface of the HTL. If the $\mathrm{Ni}\left(\mathrm{O}_{2} \mathrm{CH}\right)_{2}(\mathrm{en})_{2}$ is not completely decomposed (anneal temperature $<240{ }^{\circ} \mathrm{C}$ ), then the $\mathrm{O}_{2}$-plasma treatment does not significantly improve the NiO stoichiometry and electrical transport, and instead affects only the near surface of the thin film.

\section{Conclusions}

Thermal annealing in air and subsequent $\mathrm{O}_{2}$-plamsa treatment of solution-deposited $\mathrm{NiO}_{x}$ films spin-coated from a $\mathrm{Ni}\left(\mathrm{O}_{2} \mathrm{CH}\right)_{2}-$ en-eg-water ink have been investigated to gain an understanding of their composition and properties in relation to hole collection in PCDTBT:PC ${ }_{70} \mathrm{BM}$ solar cells. The impacts of incomplete precursor decomposition on OPV device performance are investigated with the main effect arising as increased series resistance and concomitant lowering of short circuit current. For annealing temperatures of $150{ }^{\circ} \mathrm{C}-200{ }^{\circ} \mathrm{C}$, below the decomposition temperature of the $\mathrm{Ni}\left(\mathrm{O}_{2} \mathrm{CH}\right)_{2}(\mathrm{en})_{2}$ complex, BHJ solar cells incorporating these ' $\mathrm{NiO}_{x}$ ' HTLs have low $J_{\mathrm{sc}}$ and high $R_{\mathrm{s}}$. TGA identified a lower limit of $240{ }^{\circ} \mathrm{C}$ anneal temperature that is required to ensure adequate decomposition/oxidation of the $\mathrm{Ni}\left(\mathrm{O}_{2} \mathrm{CH}\right)_{2}(\mathrm{en})_{2}$ complex. The resulting formation of $\mathrm{NiO}_{x}$ HTLs with $\sim 3.9 \mathrm{eV}$ optical gap and adequate conductivity permits efficient hole collection in BHJ devices. TGA/DSC analysis suggests such films are initially sub-stoichiometric $\mathrm{NiO}_{x}$, which helps to explain the improved performance for subsequent $\mathrm{O}_{2}$-plasma treatment to obtain a high work function and improved film stoichiometry. Results are consistent with recent reports of other $\mathrm{NiO}_{x}$ precursor formulations that produce $\mathrm{NiO}_{x}$ HTLs with similar device properties at low decomposition temperature. ${ }^{28}$ These studies show increased series resistance as a direct result of incomplete decomposition of the $\mathrm{NiO}_{x}$ precursor complex and how these resistive HTL films lead to lower $J_{\mathrm{sc}}$ in devices with concomitant performance loss.

However, for interlayers where conversion to $\mathrm{NiO}_{x}$ is performed below the decomposition temperature and is incomplete, $V_{\text {oc }}$ remains at high values. The surface chemistry and work function of the $\mathrm{NiO}_{x}$ interlayer determines the $V_{\text {oc }}$ in OPV devices whether or not the organometallic precursor has fully decomposed to form $\mathrm{NiO}_{x}$. In comparison, non-selective selfassembled molecular interlayer contacts provide paths to electron transfer from the BHJ LUMO levels and reduce quasi- $\mathrm{E}_{\mathrm{F}}$ splitting, which lead to lower $V_{\mathrm{oc}}{ }^{7}$ From the results presented here, we conclude that the nanoscale electrical changes as a function of converted precursor observed seem to strongly affect the ability of charge selective $\mathrm{NiO}_{x}$ interlayers to extract holes from the adjacent $\mathrm{BHJ}$ and transport those to the external circuit. Recently, the surface polarity of $\mathrm{NiO}_{x}$ interlayers was investigated and shown to dominate the interface properties when compared to the interlayer surface roughness and crystal structure. ${ }^{40}$ Hence, post treatment and formation of a dipolar surface with low defects is related to the increased polar component of the total surface energy. Data presented here shows that surface composition for these films are similar. However, differences in their nanoscale conductivity do not strongly affect the $V_{\mathrm{oc}}$. Hence, surface recombination velocity is 
not significantly enhanced as quasi- $\mathrm{E}_{\mathrm{F}}$ splitting seems nominally equivalent for these devices at $V_{\mathrm{oc}}$, which is consistent with steady-state and transient photocurrent studies on similar systems. ${ }^{42}$ We hypothesize that the majority of $J_{\mathrm{sc}}$ loss observed as the processing temperature is lowered below the precursor decomposition threshold proceeds via recombination in the $\mathrm{BHJ}$ and is not mediated by $\mathrm{NiO}_{x}$ surface states. If this postulate holds, then charge selectivity and efficient carrier transport are functionally separate and proceed by different mechanisms for this particular active layer. Moreover, these properties are also spatially separate as the selectivity is determined by the surface composition and local density of states that provide a low defect interface and low surface recombination while the interlayer subsurface enables charge delocalization and carrier transport to the transparent electrode. Implications for the separation of selectivity and transport mechanisms could result in designs for bilayer selective contacts and indeed examples exist in literature $^{\mathbf{8 0}}$ This can also help to decouple surface and subsurface effects of decomposition temperature, organometallic precursor formulations and subsequent surface modifications for efficient interlayer contacts in photovoltaic technologies. However in more demanding photovoltaic systems with higher carrier mobilities and photogenerated charge densities, it may be necessary to increase the $\mathrm{NiO}_{x}$ thickness in order to effectively passivate high carrier density electrodes such as TCOs and metals.

\section{Acknowledgements}

Thank you Professor Reuben T. Collins at the Colorado School of Mines for thoughtful discussions. Research supported as part of the Center for Interface Science: Solar Electric Materials, an Energy Frontier Research Center funded the U.S. Department of Energy, Office of Science, Basic Energy Sciences, under Award Number DE-SC0001084 (NRA, ELR, RER, KXS), and NREL LDRD Number ARE21000.

\section{Notes and references}

1 E. L. Ratcliff, B. Zacher and N. R. Armstrong, J. Phys. Chem. Lett., 2011, 2, 1337-1350.

2 C. Brabec, S. Gowrisanker, J. Halls, D. Laird, S. Jia and S. Williams, Adv. Mater., 2010, 22, 3839-3856.

3 J. Chen, H. Wei and K. Ho, Sol. Energy Mater. Sol. Cells, 2007, 91, 1472-1477.

4 H. Frohne, S. Shaheen, C. J. Brabec, D. Muller, N. Sariciftci and K. Meerholz, ChemPhysChem, 2002, 9, 795-799.

5 S. Khodabakhsh, B. Sanderson, J. Nelson and T. Jones, Adv. Funct. Mater., 2006, 16, 95-100.

6 P. Ndione, A. Garcia, E. Widjonarko, A. K. Sigdel, K. X. Steirer, D. C. Olson, P. A. Parilla, D. S. Ginley, N. R. Armstrong, R. E. Richards, E. L. Ratcliff and J. J. Berry, Adv Energy Mater, 2013, 3, 524-531.

7 E. L. Ratcliff, A. Garcia, S. A. Paniagua, S. R. Cowan, A. J. Giordano, D. S. Ginley, S. R. Marder, J. J. Berry and D. C. Olson, Adv. Energy Mater., 2013, 3, 647-656.
8 E. L. Ratcliff, J. Meyer, K. Steirer, N. R. Armstrong, D. C. Olson and A. Kahn, Org. Electron., 2012, 13, 744-749.

9 J. Meyer and A. Kahn, Proc. SPIE, 2011, 1, 1-7.

10 J. Meyer, A. K. Zilberberg, T. Riedl and A. Kahn, J. Appl. Phys., 2011, 110, 033710.

11 J. H. Seo, S. Cho, M. Leclerc and A. J. Heeger, Chem. Phys. Lett., 2011, 503, 101-104.

12 H. Ishii, K. Sugiyama, E. Ito and K. Seki, Adv. Mater., 1999, 11, 605-625.

13 N. R. Armstrong, P. A. Veneman, E. L. Ratcliff, D. Placencia and M. Brumbach, Acc. Chem. Res., 2009, 42, 1748-1757.

14 T. Ripolles-Sanchis, A. Guerrero, E. Azaceta, R. Tena-Zaera and G. Garcia-Belmonte, Sol. Energy Mater. Sol. Cells, 2013, 117, 564-568.

15 J. Reinhardt, M. Grein, C. Bühler, M. Schubert and U. Würfel, Adv. Energy Mater., 2014, DOI: 10.1002/ aenm.201400081.

16 M. Bolognesi, A. Sánchez-Díaz, J. Ajuria, R. Pacios and E. Palomares, Phys. Chem. Chem. Phys., 2011, 13, 6105-6109.

17 M. Irwin, D. Buchholz, A. Hains, R. Chang and T. Marks, Proc. Natl. Acad. Sci. U. S. A., 2008, 105, 2783-2787.

18 F. Liu, S. Shao, X. Guo, Y. Zhao and Z. Xie, Sol. Energy Mater. Sol. Cells, 2010, 94, 842-845.

19 V. Shrotriya, G. Li, Y. Yao, C.-W. Chu and Y. Yang, Appl. Phys. Lett., 2006, 88, 073508.

20 K. X. Steirer, P. F. Ndione, N. E. Widjonarko, M. T. Lloyd, J. Meyer, E. L. Ratcliff, A. Kahn, N. R. Armstrong, C. J. Curtis, D. S. Ginley, J. J. Berry and D. C. Olson, Adv. Energy Mater., 2011, 1, 813-820.

21 M. D. Irwin, J. D. Servaites, D. Buchholz, B. Leever, J. Liu, J. Emery, M. Zhang, J. Song, M. Durstock, A. Freeman, M. Bedzyk, M. Hersam, R. Chang, M. Ratner and T. Marks, Chem. Mater., 2011, 23, 2218-2226.

22 J. Zhang, J. Wang, Y. Fu, B. Zhang and Z. Xie, J. Mater. Chem. C, 2014, 2, 8295-8302.

23 V. Wood, M. J. Panzer, J. E. Halpert, J. M. Caruge, M. G. Bawendi and V. Bulović, ACS Nano, 2009, vol. 3, 3581-3586.

24 B. S. Mashford, T.-L. Nguyen, G. J. Wilson and P. Mulvaney, J. Mater. Chem., 2009, 20, 167.

25 J.-Y. Jeng, K.-C. Chen, T.-Y. Chiang, P.-Y. Lin, T.-D. Tsai, Y.-C. Chang, T.-F. Guo, P. Chen, T.-C. Wen and Y.-J. Hsu, Adv. Mater., 2014, 26, 4107-4113.

26 W. Chen, Y. Wu, J. Liu, C. Qin, X. Yang, A. Islam, Y.-B. Cheng and L. Han, Energy Environ. Sci., 2015, 8, 629-640.

27 L. Hu, J. Peng, W. Wang, Z. Xia, J. Yuan, J. Lu, X. Huang, W. Ma, H. Song, W. Chen, Y.-B. Cheng and J. Tang, ACS Photon., 2014, 1, 547-553.

28 J. R. Manders, S.-W. Tsang, M. J. Hartel, T.-H. Lai, S. Chen, C. M. Amb, J. R. Reynolds and F. So, Adv. Funct. Mater., 2013, 23, 2993-3001.

29 J. Jung, D. L. Kim, S. H. Oh and H. J. Kim, Sol. Energy Mater. Sol. Cells, 2012, 102, 103-108.

30 K. X. Steirer, J. P. Chesin, N. E. Widjonarko, J. J. Berry, A. Miedaner, D. S. Ginley and D. C. Olson, Org. Electron., 2010, 11, 1-5. 
31 V. Zardetto, T. M. Brown, A. Reale and A. Di Carlo, J. Polym. Sci., Part B: Polym. Phys., 2011, 49, 638-648.

32 A. A. Balandin, E. S. Grigoryan and Z. S. Yanysheva, Acta Physicochim. URSS, 1940, 12, 737-758.

33 L. L. Bircumshaw and J. Edwards, J. Chem. Soc., 1950, 18001809.

34 G. R. Rao, K. C. Patil and C. N. R. Rao, Inorg. Chim. Acta, 1970, 4, 215-218.

35 B. R. Wheeler and A. K. Galwey, J. Chem. Soc., Faraday Trans. 1, 1974, 70, 661-670.

36 A. K. Galwey and M. E. Brown, Proc. R. Ir. Acad., Sect. B, 1977, 77, 465-471.

37 A. B. Edwards, C. D. Garner and K. J. Roberts, J. Phys. Chem. $B, 1997,101,20-26$.

38 A. H. Qusti, A. A. Samarkandy, S. Al-Thabaiti and E.-H. M. Diefallah, J. King Abdulaziz Univ., 1997, 9, 73-81.

39 Z. Zhai, X. Huang, M. Xu, J. Yuan and J. Peng, Adv. Energy Mater., 2013, 3, 1614-1622.

40 N. E. Widjonarko, P. Schulz, P. A. Parilla, C. L. Perkins, P. F. Ndione, A. K. Sigdel, D. C. Olson, D. S. Ginley, A. Kahn, M. F. Toney and J. J. Berry, Adv. Energy Mater., 2014, 4, 1301879.

41 E. L. Ratcliff, J. Meyer, K. X. Steirer, A. Garcia, J. J. Berry, D. S. Ginley, D. C. Olson, A. Kahn and N. R. Armstrong, Chem. Mater., 2011, 23, 4988-2000.

42 S. R. Cowan, J. V. Li, D. C. Olson and E. L. Ratcliff, Adv. Energy Mater., 2014, 5, 1400549.

43 G. Narain, Bull. Chem. Soc. Jpn., 1966, 39, 2298-2300.

44 N. Armstrong, C. Carter, C. Donley, A. Simmonds, P. Lee, M. Brumbach, B. Kippelen, B. Domercq and S. Yoo, Thin Solid Films, 2003, 445, 342-352.

45 M. P. Seah, Surf. Interface Anal., 1989, 14, 488-488.

46 M. Ghaemy, A. Omrani and A. Rostami, J. Appl. Polym. Sci., 2005, 97, 265-271.

47 H. Icbudak, T. K. Yazicilar and W. T. Yilmaz, Thermochim. Acta, 1999, 335, 93-98.

48 K. S. Rejitha and S. Mathew, J. Therm. Anal. Calorim., 2010, 102, 931-939.

49 V. T. Yilmaz, S. Demir, O. Andac and W. T. A. Harrison, J. Coord. Chem., 2002, 55, 863-872.

50 K. S. Rejitha and S. Mathew, J. Therm. Anal. Calorim., 2008, 93, 213-217.

51 H. G. Edwards and A. Knowles, J. Mol. Struct., 1992, 268, 1322.

52 F. J. A. Garcia and M. M. P. Manrique, Ion, 1976, 36, 422-425.

53 D. Stoilova and V. Koleva, Spectrochim. Acta, Part A, 2001, 57, 2629-2636.

54 P. D. Buckley and P. A. Giguere, Can. J. Chem., 1967, 45, 397407.
55 W. Sawdony, K. Niedenzu and J. W. Dawson, Spectrochim. Acta, Part A, 1967, 23, 799-806.

56 J. A. Broomhead and L. A. P. Kane-Maguire, J. Chem. Soc. A, 1967, 4, 546-553.

57 T. Iwamoto and D. F. Shriver, Inorg. Chem., 1971, 10, 24282432.

58 J. J. A. McLean, A. F. Schreiner and A. F. Laethem, J. Inorg. Nucl. Chem., 1964, 26, 1245-1248.

59 A. Sabatini and S. Califano, Spectrochim. Acta, 1960, 16, 677688.

60 M. L. Niven and G. C. Percy, Transition Met. Chem. (Dordrecht, Neth.), 1978, 3, 267-271.

61 J. L. Bantignies, S. Deabate, A. Righi, S. Rols, P. Hermet, J. L. Sauvajol and F. Henn, J. Phys. Chem. C, 2008, 112, 2193-2201.

62 N. Bellakhal and J. L. Brisset, J. Chem. Res., Synop., 2001, 238-239.

63 D. S. Hall, D. J. Lockwood, S. Poirier, C. Bock and B. R. MacDougall, J. Phys. Chem. A, 2012, 116, 6771-6784.

64 L. Escobar-Alarcon, A. Arrieta, E. Camps, S. Romero and M. A. Camacho-Lopez, Superficies Vacio, 2005, 18, 9-12.

65 D. Forster and D. M. L. Goodgame, J. Chem. Soc., Jan., 1965, 262-267.

66 B. Mavis and M. Akinc, Chem. Mater., 2006, 18, 5317-5325.

67 H. Yang and J. L. Whitten, Surf. Sci., 1998, 401, 313-321.

68 R. Micu-Semeniuc and C. G. Macarovici, Rev. Roum. Chim., 1972, 17, 981-992.

69 H. Yang and J. L. Whitten, Journal of Chem. Phys., 1997, 107, 8518-8524.

70 A. Ludi and R. Huegi, Helv. Chim. Acta, 1968, 51, 349-355.

71 N. S. Gajbhiye and S. Prasad, Thermochim. Acta, 1996, 285, 325-336.

72 J. Kristof, A. D. Battisti, G. Keresztury, E. Horvath and T. Sziligyi, Langmuir, 2001, 17, 1637-1640.

73 W. M. H. Oo, M. D. McCluskey, A. D. Lalonde and M. G. Norton, Appl. Phys. Lett., 2005, 86, 073111.

74 E. L. Williams, R. A. Bailey and S. E. Wberley, J. Inorg. Nucl. Chem., 1970, 32, 2197-2203.

75 T. J. Taylor, D. Dollimore, G. A. Gamlen, A. J. Barnes and M. A. Stuckey, Thermochim. Acta, 1986, 101, 291-304.

76 S. Srinivasan and S. Ganguly, Catal. Lett., 1991, 10, 279-288. 77 F. Urbach, Phys. Rev., 1953, 1324.

78 A. Fujimori and F. Minami, Phys. Rev. B: Condens. Matter Mater. Phys., 1984, 30, 957-971.

79 S. Hüfner, Adv. Phys., 1994, 43, 183-356.

80 J. D. Zimmerman, B. Song, O. Griffith and S. R. Forrest, Appl. Phys. Lett., 2013, 103, 243905. 